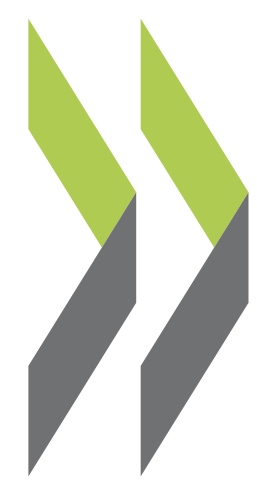

OECD Economics Department Working Papers No. 663

Long-Run GDP Growth Framework and Scenarios for the World Economy
Romain Duval,

Christine de la Maisonneuve 
Organisation de Coopération et de Développement Économiques

Organisation for Economic Co-operation and Development

\section{ECONOMICS DEPARTMENT}

English - Or. English

Cancels \& replaces the same document of 03 February 2009

LONG-RUN GDP GROWTH FRAMEWORK AND SCENARIOS FOR THE WORLD ECONOMY

ECONOMICS DEPARTMENT WORKING PAPERS No.663

By Romain Duval and Christine de la Maisonneuve

All Economics Department Working Papers are available through OECD's internet web site at www.oecd.org/eco/Working_Papers 


\section{ABSTRACT/RÉSUMÉ}

\section{Long-run GDP growth framework and scenarios for the world economy}

This paper develops and applies a simple "conditional growth" framework to make long-term GDP projections for the world economy, taking as a starting point recent empirical evidence about the importance of total factor productivity and human capital in explaining current cross-country disparities in GDP per capita levels. Other distinct features of the projection framework include human capital projections by cohorts and implicit allowance for the impact of ageing and potential labour market and pension reforms on future growth in employment levels. In the baseline projection, world GDP would grow in PPP terms by about $33 / 4 \%$ per year on average over the period 2005-2050. When expressed in constant market exchange rates, this projection falls roughly in the middle of the range of long-run scenarios recently developed in the context of greenhouse gas emission projections. The sensitivity of the projection to total factor productivity and population growth assumptions is significant, however, and compounds with deeper sources of uncertainty such as model and parameter uncertainty.

JEL classification: O11; O43; O47; O57; Q43; Q54.

Keywords: Growth; Long run; Projections; Human Capital; Cohorts.

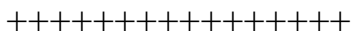

\section{Un cadre d'analyse et des scénarios de croissance à long terme pour l'économie mondiale}

Cet article développe et applique un cadre d'analyse simple fondé sur la «convergence conditionnelle » pour produire des projections de long terme du PIB mondial, prenant pour point de départ l'évidence empirique récente concernant l'importance de la productivité multifactorielle et du capital humain dans l'explication des disparités actuelles de niveaux de PIB par habitant entre pays. Les autres traits distinctifs du cadre d'analyse incluent des projections de capital humain par cohortes, ainsi que la prise en compte implicite de l'impact du vieillissement et des réformes du marché du travail et des régimes de retraite sur la croissance future de l'emploi. Dans la projection centrale, le PIB mondial exprimé en PPA croîtrait à un rythme annuel d'environ 3 3/4\% en moyenne au cours de la période 2006-2050. Exprimé en taux de change de marché constants, cette projection se situe dans le milieu de la fourchette des scénarios de long terme développés récemment dans le contexte des projections d'émissions de gaz à effet de serre. Cependant, la sensibilité de la projection aux hypothèses de taux de croissance de la productivité multifactorielle et de la population est forte, et se combine à des sources d'incertitude plus profondes relatives au modèle et à la valeur des paramètres.

Classification JEL: O11; O43 ; O47 ; O57 ; Q43 ; Q54.

Mots-Clés : Croissance ; Long terme ; Projections ; Capital humain ; Cohortes.

\section{Copyright OECD 2009}

Application for permission to reproduce or translate all, or part of, this material should be made to: Head of Publications Service, OECD, 2 rue André Pascal, 75775 Paris CEDEX 16. 
TABLE OF CONTENTS

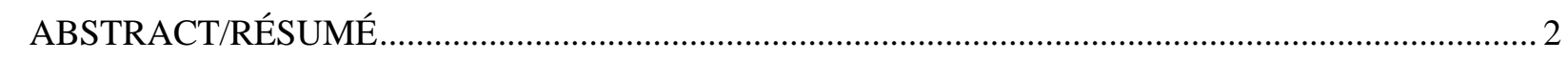

LONG-RUN GDP GROWTH FRAMEWORK AND SCENARIOS FOR THE WORLD ECONOMY ...... 5

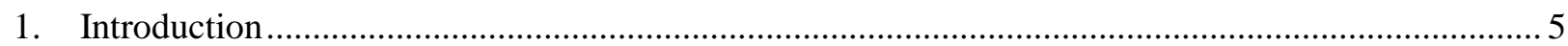

2. Theoretical framework and basic assumptions underlying its empirical implementation .................. 6

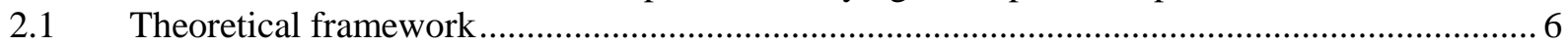

2.2 Basic assumptions underlying the empirical implementation of the theoretical framework ...... 8

3. Baseline economic scenario for the world economy up to 2050 ................................................. 10

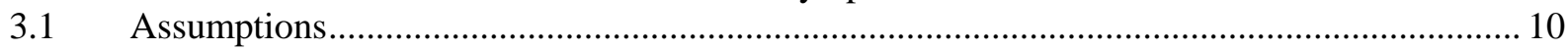

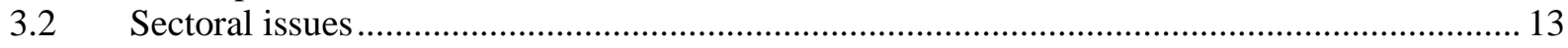

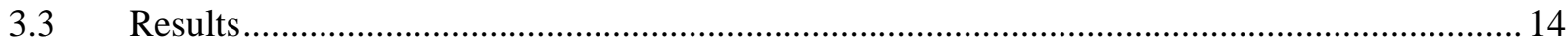

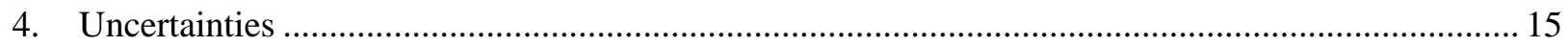

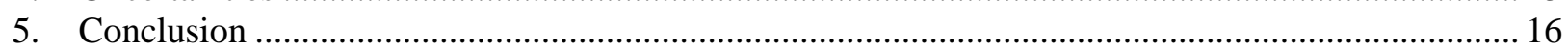

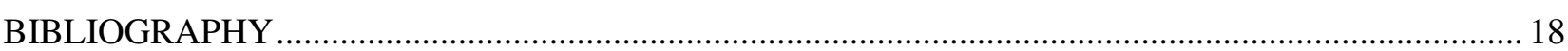

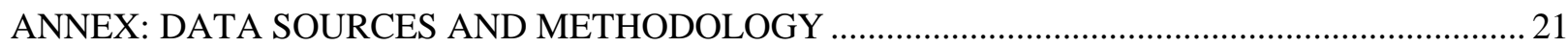

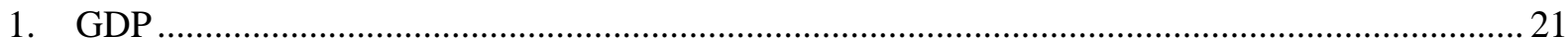

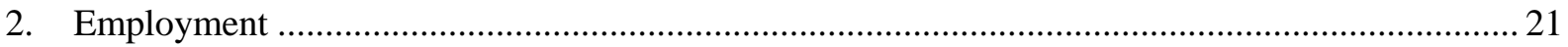

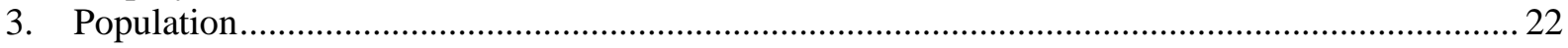

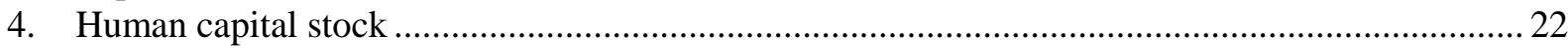

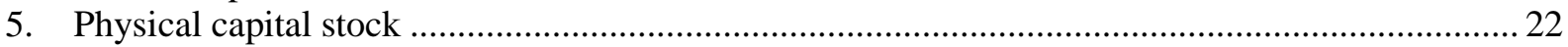

\section{Boxes}

Box 1. Disentangling the long-run drivers of GDP per capita .......................................................... 
ECO/WKP(2009)4 
ECO/WKP(2009)4

\title{
LONG-RUN GDP GROWTH FRAMEWORK AND SCENARIOS FOR THE WORLD ECONOMY
}

\author{
By Romain Duval and Christine de la Maisonneuve ${ }^{1}$
}

\section{Introduction}

1. A long-term growth framework for the world economy is key to exploring a number of long-run economic issues, such as ageing, fiscal sustainability, migrations, or natural resources. Baseline economic scenarios have proliferated in recent years in the context of climate change projections, such as those developed by the Intergovernmental Panel on Climate Change (IPCC), which typically assume a convergence process whereby the income levels of less-developed countries gradually, and at least partially, catch-up to those of more developed economies. ${ }^{2}$ The vast majority of projections focus on convergence at the macroeconomic level, in terms of GDP per capita or GDP per worker (the "top-down" approach) while a few others assume some gradual catch-up at the sectoral level (the "bottom-up" approach). ${ }^{3}$ In both cases, climate modellers have typically relied on simple assumptions regarding the form and the speed of convergence, without explicitly specifying the policy assumptions underlying their scenarios. This, and the fact that in the IPCC's Special Report on Emission Scenarios (SRES) a large number of possible outcomes are presented as being equally likely, may have contributed to strengthening the impression of uncertainty that is inherent to any long-run world economic projections. ${ }^{4}$

2. In this paper, special emphasis is put on setting up a theoretical framework that explicitly integrates some of the current theoretical and empirical knowledge regarding the long-run drivers of economic growth. At the same time, reflecting both data constraints and the wide diversity of existing

1 The authors are Principal Administrator and Statistical Assistant at the OECD Economics Department, respectively. (Email: romain.duval@oecd.org; christine.maisonneuve@oecd.org ). They would like to express gratitude to Jean Chateau for running the ENV-Linkages model simulations. They also want to thank Jorgen Elmeskov, Giuseppe Nicoletti and Jean-Luc Schneider for helpful comments. Thanks too to Irene Sinha for editorial assistance. The authors retain full responsibility for errors and omissions.

2 See in particular Nakicenovic et al. (2000).

3 See, for instance, the approach followed by McKibbin et al. (2004) using the G-Cubed model. One difficulty with the "bottom-up" approach is that it relies on comparisons of sectoral labour productivity levels across countries which, in turn, requires the use of PPP exchange rates at the sector level. Insofar as these data do not exist for the vast majority of countries, strong assumptions have to be made when constructing them.

See Nakicenovic et al. (2000), as well as the recent update provided in Fisher et al. (2007). Figure 3.2 p.180 in the latter paper indicates that even when ignoring the most extreme scenarios, projected world GDP in 2100 could lie anywhere between less than 100 billion US\$ $1990\left(5^{\text {th }}\right.$ percentile of the distribution of SRES scenarios) and more than 500 billion US\$ $1990\left(95^{\text {th }}\right.$ percentile $)$. 
growth theories, ${ }^{5}$ a simple and fairly consensual framework is retained, in which GDP per capita depends on technology, investment in physical capital, investment in human capital and the employment rate, and "conditional growth convergence" applies. With this framework at hand, a baseline scenario can be constructed based on explicit assumptions regarding each of the four growth drivers. As well, plausible alternative scenarios can be built up in order to roughly assess the degree of uncertainty surrounding the projections, while still placing some bounds on the future path of world GDP.

3. Against this background, the paper proceeds as follows. Section 2 presents the theoretical framework underlying the long-run GDP projections. Section 3 discusses the assumptions made within this framework in order to construct a baseline scenario, including at the sectoral level, and provides the associated GDP projections. Section 4 briefly reviews the inherently large uncertainties surrounding such projections and illustrates some of these uncertainties through simple sensitivity analysis. Section 5 concludes.

4. It should be stressed upfront that the projections presented in this paper were built as part of an OECD project on the Economics of Climate Change Mitigation which was carried out in the course of 2008 (Burniaux et al. 2008). As a result, they do not incorporate the sharp deterioration in world economic activity and forecasts that occurred during the second half of 2008. Factoring in this slowdown would imply a downward revision of world GDP growth over the first 5-10 years of the projection period, but would be expected to have very small, if any, effects over the period up to 2050, at least insofar as long-run potential growth is only marginally affected.

\section{Theoretical framework and basic assumptions underlying its empirical implementation}

\subsection{Theoretical framework}

5. While there is no agreement on any single theoretical model of economic growth, a basic empirical consensus - including previous OECD work - seems to support the so-called "conditional convergence" hypothesis. ${ }^{6}$ This hypothesis basically states that a country's growth rate in GDP per capita should be negatively related to the starting level of its GDP per capita conditional on fixed values of other variables, including inter alia investment rates in physical and human capital, policies and institutions more broadly, demographics, geography etc. As a result, each country would be expected to converge to its own steady-state level of GDP per capita determined by the above-mentioned variables. Because the latter vary across countries, in the long-run differences would remain in per capita income levels but not in growth rates.

6. In order to incorporate the conditional convergence hypothesis into the projections, this paper adopts the most widely-used theoretical framework in recent empirical analyses of cross-country disparities in per-capita incomes (Caselli, 2005; Caselli and Coleman, 2006; Easterly and Levine, 2001; Hall and Jones, 1999; Jones, 1997; Klenow and Rodriguez-Clare, 1997; OECD, 2004). Cross-country variation in the levels of output per worker is typically decomposed into parts attributed to the variation in physical and human capital per worker and total factor productivity (TFP). Such exercises have found TFP and - to a lesser extent - human capital to be the main drivers of current disparities in living standards between developed and developing economies. ${ }^{7}$ With such decomposition at hand, long-run output per

5 See Barro and Sala-i-Martin (2004). For an overview of the potential implications of growth theories for global convergence scenarios, which was the topic of an OECD workshop held on 16 January, 2006, see Vanston (2006).

6 Barro and Sala-i-Martin (2004), OECD (2004).

7 In turn, cross-country differences in levels of TFP and/or human capital may reflect differences in policies and institutions. Analysing such factors goes beyond the scope of the present paper. 
worker scenarios for each country may then be built up by projecting each of the three components (see e.g. Jones, 1997).

7. Concretely, as shown in Box 1, based on a standard aggregate Cobb-Douglas production function with physical capital, human capital, and labour as production factors and labour-augmenting technological progress, and assuming that production function is invariant both across countries and over time, GDP per capita can be decomposed as follows: ${ }^{8}$

$$
Y_{t} / \operatorname{Pop}_{t}=\left(K_{t} / Y_{t}\right)^{\alpha /(1-\alpha)} A_{t} h_{t}\left(L_{t} / \operatorname{Pop}_{t}\right)
$$

where $K_{t} / Y_{t}, A_{t}, h_{t}$, and $L_{t} / P_{p o p}$ denote the capital/output ratio, TFP, human capital per worker and the employment rate (defined here as the ratio of employment to total population), respectively, and $\alpha$ is the capital share in aggregate output.

Such decomposition can be performed for a base year, and long-run projections then be made for each of the four components in order to project the future path of GDP per capita.

\section{Box 1. Disentangling the long-run drivers of GDP per capita}

Consider a standard Cobb-Douglas production function with capital and skilled labour and labour-augmenting (Harrodneutral) technological progress:

$Y_{t}=K_{t}^{\alpha}\left(A_{t} H_{t}\right)^{1-\alpha}=K_{t}^{\alpha}\left(A_{t} h_{t} L_{t}\right)^{1-\alpha}$

where $\mathrm{Y}, \mathrm{K}, \mathrm{H}, \mathrm{h}, \mathrm{L}$ and $\mathrm{A}$ denote output, physical capital, effective labour input, human capital per worker, employment and TFP, respectively. After some basic manipulations, this can be re-written as:

$Y_{t} / L_{t}=\left(K_{t} / Y_{t}\right)^{\alpha /(1-\alpha)} A_{t} h_{t}$

GDP per capita and GDP can then be written respectively as (with Pop denoting population):

$Y_{t} / \operatorname{Pop}_{t}=\left(Y_{t} / L_{t}\right)\left(L_{t} / \operatorname{Pop}_{t}\right)=\left(K_{t} / Y_{t}\right)^{\alpha /(1-\alpha)} A_{t} h_{t}\left(L_{t} / P_{o p}\right)$

and:

$Y_{t}=\left(Y_{t} / L_{t}\right)\left(L_{t} /\right.$ Pop $\left._{t}\right) \operatorname{Pop}_{t}=\left(K_{t} / Y_{t}\right)^{\alpha /(1-\alpha)} A_{t} h_{t}\left(L_{t} /\right.$ Pop $\left._{t}\right)$ Pop $_{t}$

Cross-country differences in GDP per capita at any point in time can thus be decomposed into four components: ${ }^{1}$

- Capital/output ratios

- Human capital per worker

- TFPs

- Employment rates

1. In principle, hours worked could also be incorporated as another driver of cross-country differences in GDP per capita. In practice, however, this would be feasible only for OECD countries, due to data availability constraints. This factor is therefore

8 The constant-returns-to-scale assumption excludes de facto the possibility of permanent growth effects of the human capital stock. While some empirical literature hints at endogenous growth effects of human or even physical capital (see e.g. Bassanini and Scarpetta, 2004; Bond et al., 2004), this issue remains fairly controversial in practice (e.g. Sianesi and Van Reenen, 2003). 
omitted from the framework. This means that any cross-country differences in hours worked will ultimately be captured as crosscountry differences in TFP, and any TFP convergence scenario will also implicitly include an hours worked convergence scenario.

\subsection{Basic assumptions underlying the empirical implementation of the theoretical framework}

8. In order to perform the decomposition featured in equation (1) for a base year, comparable data are needed across countries for labour productivity, TFP, the capital/output ratio, human capital per worker and the employment rate. This in turn implies a number of simplifications to facilitate harmonisation, not least regarding physical capital stocks. Data sources and data construction methodology are described in detail in the Annex. The key features of the data are the following:

- Two base years are considered, 1995 and 2005.

- Labour productivity levels are computed for each country as the ratio of GDP in 2005 constant PPP US\$ to employment, using the latest PPP estimates published within the context of the International Comparison Program (ICP) coordinated by the World Bank (World Bank, 2007). These include noticeable revisions with respect to past estimates, which had been shown to overstate aggregate price gaps and therefore to understate PPP income gaps between developed and developing countries. ${ }^{9}$ As a result, income gaps between developed and developing countries have been typically revised upwards, with potentially important implications for future world GDP growth within the context of convergence scenarios. ${ }^{10}$

- Capital stocks (in constant 2005 national currency prices) are built up from investment series through the perpetual inventory method, assuming a 5\% annual depreciation rate. ${ }^{11}$ Long investment time series - dating back at least to the early 1970s - are used, so that capital stock estimates in 1995 and 2005 are largely insensitive to the choice of the initial value. ${ }^{12}$ The capital

This is due in part to past estimates relying on the so-called "Geary-Khamis" technique for constructing GDPs in PPPs, which has been shown to overestimate the relative incomes of poor countries. Other available approaches, including the so-called "EKS" method now used for most countries, have been found to be less biased in this regard (at least under homothetic consumer preferences, see Neary, 2004). See World Bank (2007), as well as Nordhaus (2007) for some discussion of this issue within the context of climate models.

For instance, GDP per capita levels in China and India for the year 2005 are now estimated to be equal to about $10 \%$ and $5 \%$ of the US level, respectively, versus $16 \%$ and $8 \%$ previously, although the revision may also reflect other factors including the use of more recent price survey data.

This very simple method was chosen for two reasons: $i$ ) it allows capital stocks to be constructed for a large number of countries, including many developing countries; ii) it allows capital-output ratios to be compared across countries, which is essential in the context of convergence scenarios. However, one drawback of the approach - and one potential source of bias both across countries and over time - is to ignore changes in the relative price of investment, and in particular the trend decline in the price of information and communication technologies. This decline has contributed to the gradual shift to chainweighting in the National Accounts of most OECD countries.

The initial value of the capital stock is computed as $I_{0} /(\delta+g)$, where $I_{0}$ denotes investment for the first available year, $\delta$ is the depreciation rate of the capital stock (set here at 5\%) and $g$ is average GDP growth rate between periods 0 and 10. This is the capital stock that would prevail along a balanced growth path where GDP growth and the investment rate would be constant. While applying this common methodology to all countries yields rather crude capital stock series for those countries where such data are readily 
stock estimate is then divided by GDP (also expressed in constant 2005 national currency prices) to obtain the capital/output ratio.

- Human capital stocks are constructed in two steps. In a first step, data on the average number of years of schooling across population aged 25-64 are assembled for a wide range of countries, using primarily the dataset constructed by Cohen and Soto (2007), ${ }^{13}$ which in turn is consistent with, but improves on the well-known Barro-Lee dataset. ${ }^{14}$ In a second step, the average number of years of schooling across the population is converted into a human capital stock based on an assumption regarding returns to education. Following the seminal paper by Hall and Jones (1999), and relying on microeconomic evidence on returns to schooling for many countries surveyed in Psacharopoulos (1994) and Psacharopoulos and Patrinos (2002), the marginal return to schooling is set equal to $13.4 \%$ for the first four years of education, $10.1 \%$ for the next four and $6.8 \%$ beyond the eighth year. ${ }^{15}$ While the magnitude of social returns to education - and of possible externalities to education in particular - remains subject to uncertainty, the general pattern of falling returns by level of education is well established, and a 6.5\%-7\% average return to upper secondary and tertiary education is fairly consistent with both microeconomic and macroeconomic evidence. ${ }^{16}$

- TFP is then derived from GDP per capita, physical capital stock, human capital stock and employment rate data, re-arranging equation (1) as follows:

$A_{t}=\left(Y_{t} /\right.$ Pop $\left._{t}\right) /\left[\left(K_{t} / Y_{t}\right)^{\alpha /(1-\alpha)} h_{t}\left(L_{t} /\right.\right.$ Pop $\left.\left._{t}\right)\right]$, where the capital share $\alpha$ is set equal to $1 / 3$.

9. Results from this decomposition are presented in Table 1 for the year 2005. In line with findings from recent literature - which Easterly and Levine (2001) labeled the "new stylised facts of growth", and in contradiction with basic neo-classical growth theory, ${ }^{17}$ TFP appears to be the main driver of existing

available from National Accounts, its key strength within the present context is to vastly expand the set of countries covered and to allow for cross-country comparisons of capital/output ratios.

See Cohen and Soto (2007) and Annex for details. Thanks are due to Marcelo Soto for providing these data.

Barro and Lee (1993, 2001).

Formally, it is assumed that human capital per worker can be written as $h_{t}=e^{\phi(S)}$, where $\mathrm{S}$ denotes the number of years of schooling, and $\phi(S)$ is chosen to be a piecewise linear function in order to reproduce the three different marginal returns to education used here for three different levels of education. Bils and Klenow (2000) argue that such specification is the appropriate way to incorporate years of schooling into an aggregate production function. An additional year of schooling increases both "effective" labour input in equation (1) and the real wage by $100 \phi^{\prime}(\mathrm{S}) \%$, which is the marginal (Mincerian) rate of return to schooling.

Meta analysis of microeconomic studies provided by Harmon et al. (2003) concludes to an average 6.5\% return to schooling across a wide range of OECD countries, datasets and model specifications. Boarini and Strauss (2007) obtain average private internal rates of return to tertiary education of about $8 \%$ on average across 21 OECD countries over the period 1991-2005. Based on panel data growth regressions for a sample of OECD countries, Bassanini and Scarpetta (2001) find an implicit 6\% marginal (social) rate of return to education at the sample mean of 10 years of average education. This is in line with the implicit $5.9 \%$ return found in Gemmel (1996).

See e.g. Mankiw et al. (1992), based on a similar production function to that used in the present paper. 
cross-country differences in GDP per capita, especially between developed and developing countries. ${ }^{18}$ Human capital is also found to play an important role. This suggests that both these factors are likely to be the major drivers of any long-run convergence scenario.

\section{[Table 1. Decomposition of cross-country differences in GDP per capita into their broad determinants (2005)]}

\section{Baseline economic scenario for the world economy up to 2050}

\subsection{Assumptions}

10. Up to 2008, GDP, investment and employment projections are taken from the OECD Economic Outlook for OECD countries as well as for Brazil, China, India and Russia, and from the IMF World Economic Outlook for all other countries. This allows some extension of the GDP decomposition presented in Table 1 up to 2008. Starting from 2009, scenarios are then drawn for each of the four GDP components for each country up to 2050. These scenarios are described below, followed by a description of the approach adopted for those countries - representing about 10\% of world GDP - where the projection framework cannot be applied due to lack of accurate data.

\section{TFP growth scenario}

11. Because technology circulates freely across the world at least in the long run, it seems reasonable to expect TFP levels in lagging countries to gradually catch up to those of technological leaders. At the same time, a host of factors, including persistent cross-country differences in policies and institutions, may prevent full convergence. The baseline scenario implicitly assumes that such factors will continue to play a role in the future, albeit to a lower extent than they do today. More concretely, it is assumed that TFP in lagging countries will ultimately converge not to the technological frontier but rather to the (lower) average of TFP levels in "high-TFP" OECD countries. Concretely, the baseline TFP scenario rests on the following assumptions:

- The average TFP level across those OECD countries whose TFP levels stand above the OECD average is calculated for $2005 .{ }^{19}$ This TFP level across "high-TFP" economies is then assumed to grow at a $1.5 \%$ annual rate between 2009 and $2050 .{ }^{20}$ The resulting path is assumed to be the "frontier" towards which all lagging countries converge. The 1.5\% TFP growth assumption implies that in the long run, assuming the educational attainment of younger generations ultimately levels off and the capital/output ratio stays constant, labour productivity will also grow at $1.5 \%$ a year.

\footnotetext{
18 Cross-country variance in the logarithm of TFP is found to account for over half of the cross-country variance in the logarithm of GDP per capita. Netherlands, Norway, Spain, Sweden, the United Kingdom and the United States. in the dataset, and yields medium-term potential GDP growth estimates for this country which are consistent with OECD medium-term projections.
} 
- For lagging countries and up to 2015 , recent TFP trends are extrapolated by assuming these countries converge to the above "frontier" at the average rate observed for each country over the period 1995-2005 (set equal to zero if they actually diverged). ${ }^{21}$

- Between 2015 and 2025, the speed of convergence is assumed to converge gradually to a $2 \%$ annual rate. This corresponds to the average estimated speed of convergence in GDP per capita across a wide range of datasets and econometric methods reported by Barro and Sala-i-Martin (2004). ${ }^{22}$ Applying such speed of convergence to TFP seems reasonable given that TFP is the main driver of cross-country differences in GDP per capita levels and growth rates. ${ }^{23}$ Incidentally, this figure is also not inconsistent with the 3\% TFP convergence speed estimated in recent OECD work (Nicoletti and Scarpetta, 2003) for a sample of OECD countries. ${ }^{24}$

- Beyond 2025, lagging countries converge to the "frontier" at a $2 \%$ annual rate, i.e. the TFP gap with respect to frontier closes by $2 \%$ each year.

\section{Human capital accumulation scenario}

12. Two main stylised facts stand out regarding world accumulation of human capital, which can be useful for the projection. ${ }^{25}$ First, based on the historical dataset by cohorts used in this paper, educational attainment of the 25-29 age group increased on average at a fairly regular pace of about 1.2 years per decade between 1960 and 2000 in less-educated countries. ${ }^{26}$ Second, educational attainment has tended to level off in those countries where it was highest, e.g. Australia, Switzerland or the United States. A hypothesis that may be drawn from this observation is that the speed of human capital accumulation typically slows as educational attainment increases. The baseline human capital scenario is, therefore, constructed as follows:

- Educational attainment of the 25-29 age group is projected to remain constant in the future in the country where it is currently highest (South Korea, with 14.4 years of education in 2000).

- Up to 2015, recent trends are extrapolated by assuming that all other countries converge to the above "frontier" at their average 1990-2000 speed (set equal to zero if educational attainment actually declined over this period).

21 The dynamic annual equation used is: $d \ln \left(\mathrm{TFP}_{\mathrm{t}}\right)=\mathrm{d} \ln \left(\mathrm{TFP}_{\mathrm{t}}^{*}\right)-\beta\left[\ln \left(\mathrm{TFP}_{\mathrm{t}-1}\right)-\ln \left(\mathrm{TFP}_{\mathrm{t}-1} *\right)\right]$, where $\mathrm{TFP}^{*}$ is the "frontier" described in the text and $\beta$ is the average speed of convergence observed over the period 1995-2005.

Summing up the evidence, the authors argue p.497 that "one surprising result is the similarity of the speed of $\beta$ convergence across data sets. The estimates of $\beta$ are around 2-3\% per year in the various contexts".

For some decomposition of contributions to cross-country differences in GDP per capita levels, see Table 1 above, as well as Hall and Jones (1999). For some decomposition of contributions to cross-country differences in GDP per capita growth rates, see Easterly and Levine (2001).

It may also be worth pointing out that such speed of convergence is also close to that observed for China over the period 1995-2005, and above that observed for India.

In line with the theoretical framework adopted, one strong assumption made here is that educational convergence impacts on, but is not influenced by income convergence.

This is the average increase across all countries for which data are available, excluding those 15 countries where educational attainment was highest back in 1960. 
- Between 2015 and 2025, the speed of convergence is assumed to converge gradually to the average speed observed in the average world country ${ }^{27}$ over the period 1960-2000.

- Beyond 2025, countries converge to the "frontier" at the average speed observed in the average world country over the period 1960-2000.

- Based on this scenario for the 25-29 age group, future educational attainment across the population aged 25-64 is projected through cohort effects, and then converted into a human capital stock based on the returns to education assumptions described above. ${ }^{28}$

\section{Physical capital accumulation scenario}

13. In a world where international capital is at least partly mobile, future physical capital accumulation at the country level should be driven at least partly by real interest rates at the world level, which in turn should reflect the world saving-investment equilibrium. Unfortunately, in the absence of a truly global, integrated world growth framework, world saving trends cannot be factored in the analysis undertaken here, so that their impact on future world investment via real interest rates cannot be explored. This is certainly an area for future development of the above framework. Nevertheless, it is still possible to incorporate the fact that capital/output ratios should not diverge permanently across countries in a world of integrated capital markets, as this would imply permanent cross-country differences in the marginal return to capital. ${ }^{29}$ This is implemented here as follows:

- The US investment rate path is assumed to gradually stabilise the capital/output ratio at its current level. This implicitly assumes that the United States is on a balanced growth path.

- Investment rates in all other countries are projected to vary in such a way that their capital/output ratios converge gradually to the US level. Full convergence is assumed to be reached only by 2080 , i.e. beyond the horizon of the scenario presented here. ${ }^{30}$

\section{Employment scenario}

14. The TFP, physical capital and human capital projections need to be combined with an employment projection in order to yield a baseline GDP scenario for each country. Future employment is forecast by decomposing employment into population, the participation rate and the unemployment rate, and then by assuming the following paths for each of these three components:

- Population projections are taken from the baseline United Nations (UN) scenario up to 2050.

- Participation rates are projected in two steps. First, in the top quintile of OECD countries where participation is currently highest, ${ }^{31}$ future effective retirement ages are partially indexed to life

Excluding those 15 countries where educational attainment was highest back in 1960 .

For those few countries where educational attainment data by cohorts is not available (Czech Republic, Croatia, Hong Kong, Iceland, Pakistan, Poland, Slovak Republic, Slovenia, Russia, South Africa), the projection method was applied directly to the 25-64 age group.

The marginal return to capital is equal to $\alpha \mathrm{Y} / \mathrm{K}$ in the theoretical framework used here.

Formally, the investment rate path chosen for each country is the smoothest possible path that meets the constraint that the capital/output ratio is equal to the US level in 2080.

These countries are Canada, Denmark, Iceland, New Zealand, Norway and Sweden. 
expectancy, so as to maintain a constant share of life spent in retirement. Second, in all other countries where data by cohorts are available, participation for each age group is assumed to converge gradually to the average of the top quintile. ${ }^{32}$ Aggregate participation rates are then projected using the cohort approach presented in Burniaux et al. (2003). For those countries where data by cohorts are not available, the convergence assumption is similar but is applied directly to aggregate participation rather than to the participation of each individual age group.

- Unemployment rates are assumed to converge gradually to $5 \%$ by 2050 .

\section{Baseline scenario for those countries where the framework cannot be applied}

15. The above approach is applied to 76 individual countries covering over $90 \%$ of world GDP and world population in 2005. For all other countries, human and/or physical capital data are too scarce or too unreliable to apply the same framework with a reasonable degree of confidence. In a number of cases, for instance, the period over which investment series are available is too short to be able to estimate capital stocks with a reasonable degree of confidence. The approach followed for these countries is to apply to labour productivity the methodology applied to TFP for those countries where the above framework could be applied. ${ }^{33}$

\subsection{Sectoral issues}

16. One missing element from most aggregate projections, especially those made within the context of climate policy analysis, is that GDP is seldom endogenised for those areas where fossil fuels extraction makes a sizeable share of overall output. For example, it makes little sense to project future GDP in OPEC countries regardless of the future paths of oil supply. In order to overcome this issue, for those countries where fossil fuels matter, the convergence scenarios described above are in fact applied not to GDP but rather to GDP excluding the mining and quarrying sector. ${ }^{34}$ GDP excluding mining and quarrying is projected using the approach described in Section 3.1, and the value added in mining and quarrying - and therefore overall GDP - is then determined by running the OECD's global, multi-sector, general equilibrium model ENV-Linkages. With its nested-CES structure featuring a detailed representation of energy inputs at the sectoral level, the model is particularly suitable to project energy supply, demand and prices. ${ }^{35}$

17. OECD ENV-Linkages being a multi-sector model, the variables projected in Section 3.1 for the economy as a whole are not sufficient to run it, and sectoral assumptions are required. Such assumptions are also useful per se because various long-run economic projection exercises have a major sectoral dimension, not least greenhouse gas emission projections. The starting point for projecting sectoral output and value-added growth is that history consistently points to different productivity trends across sectors, as

\footnotetext{
32 Countries for which participation data by cohorts are available include the OECD countries, Brazil, Russia, India and China. Assuming convergence in participation by age group rather than on aggregate allows taking into account permanent cross-country differences in participation that may still be associated with country-specific demographics.

Finally, for those (very) few countries and geographical areas where labour productivity data in levels are not available, labour productivity growth is assumed to be equal to average world labour productivity growth over the projection period.

These countries are OPEC countries as well as Norway and Russia. In the latter two countries, it also has to be assumed that the capital/output ratio in the mining and quarrying sector is similar to that in the rest of the economy.

For an overview of the OECD ENV-Linkages model, see Burniaux and Chateau (2008).
} 
illustrated for instance by the long sector-level productivity growth time series assembled by the Groningen Growth and Development Centre for a wide range of countries (Groningen Growth and Development Centre, 2006; Van Ark, 1996; Timmer et al. 2007). Productivity growth has typically been found to be faster in agriculture and manufacturing than in construction, transport and - to an even greater extent - other services. One challenge is, therefore, to build up for each country a sectoral productivity growth scenario that factors in the continuation of these historical patterns while still being consistent with the aggregate productivity growth scenario - excluding the mining and quarrying sector, whose output is determined endogenously by the model - described in Section 3.1. This is done here by calibrating sectoral productivity growth in the OECD ENV-Linkages model in such a way that particular relative sectoral productivity growth patterns and the aggregate productivity growth scenario (excluding mining and quarrying) both hold ex-post. The relative sectoral productivity growth patterns are assumed to be the following:

- Recent relative sectoral productivity growth patterns observed in each country over the past 1520 years $^{36}$ are extrapolated in the short run, but they are assumed to converge by 2025 to the average historical patterns observed over 1950-2000 across those 10 OECD countries where long time series exist. ${ }^{37}$

- Average historical patterns apply to all countries beyond 2025. The implicit assumption is that past relative sectoral productivity growth trends across developed countries offer a good indication of the future path developing countries will follow. It is also assumed that past patterns will continue to hold in developed countries, with faster productivity growth in agriculture and manufacturing than in services. This seems plausible given that no major break has been observed so far in these patterns, although productivity growth in services picked up during the late 1990s and early 2000s in a few developed countries, including the United States.

18. The approach followed in this paper also addresses the criticisms made recently in the climate change economics literature towards using market exchange rate (MER)-based economic projections. These constitute the vast majority of scenarios published over the past two decades, including in the IPCC SRES (Castles and Henderson, 2003a, 2003b; Henderson, 2005). Price levels expressed in common currency are typically higher in developed countries than in developing ones, due to the "Baumol-BalassaSamuelson" effect. As a result, current cross-country differences in income per capita levels tend to be over-estimated when MERs are used to convert national GDPs into a common currency. Within the context of any convergence scenario, such over-estimation is likely to translate into an over-estimation of future GDP and greenhouse gas emissions growth, ceteris paribus. In the present paper, no such problem arises because PPPs, not MERs, are used to compare initial income per capita levels and compute the economic convergence scenario.

\subsection{Results}

19. The main features of the baseline economic scenario are presented in Tables 2 and 3. The baseline scenario in PPP US\$ (Table 2) is roughly in line with - albeit somewhat below - recent OECD projections up to 2025 (Hervé et al. 2007). World GDP per capita growth is projected to be higher in PPP

36 The exact time span considered varies across countries, depending on the exact period covered by the Groningen Growth and Development Centre databases used here. As well, while sectoral productivity growth data are available for all large emitters and more, many - e.g. African and Middle Easterncountries are not covered. For the latter, the average historical patterns across those 10 OECD countries where long time series exist are assumed to hold throughout the whole projection period.

These countries are Denmark, France, Germany, Italy, Japan, the Netherlands, Spain, Sweden, the United Kingdom and the United States. 
US\$ than in constant 2005 MER US\$, due to the smaller weight assigned to fast-growing countries in the latter case. When expressed in constant MER US\$, baseline world GDP per capita growth up to 2030 falls roughly in the middle of the 1\%-3.1\% range provided in the IPCC SRES, which also relies on constant MER US\$.

20. Applying the long-run growth framework also yields a number of interesting country-specific findings, such as the fact that growth could be lower in China than in India over the coming decades. This is because compared with India, China is already fairly capital intensive, has virtually no room for further raising labour force participation, and is bound to face a significant slowdown in population growth.

[Table 2. Baseline economic scenario: main features]

[Table 3. Baseline economic scenario: population and employment projections]

\section{Uncertainties}

21. Long-run economic growth projections are inherently speculative. Uncertainties compound at several levels. First, there is model uncertainty, i.e. the most appropriate growth model is unknown and could feature a very wide range of determinants, as the empirical growth literature illustrates. ${ }^{38}$ Second, there is parameter uncertainty, i.e. the magnitude - and in some cases even the nature - of the growth impact of any given determinant is uncertain. Third, even under the extremely optimistic assumption that the framework developed in Section 3.1 builds on the right model and parameters, all of the growth drivers it features, be they TFP growth - especially in catching-up economies - physical and human capital accumulation, demographic trends or labour force participation, are hard to predict, and their ex-ante probability distribution is unknown. For all three reasons, full sensitivity analysis around the baseline world GDP growth scenario presented in Section 3 is impossible.

22. Still, as an illustration of the magnitude of the uncertainties involved, a simple sensitivity exercise is carried out here, in which world GDP growth projections are re-run under alternative assumptions regarding TFP growth in "high-TFP" countries, the speed of TFP catch-up in lagging countries, capital intensity, human capital accumulation, employment rates and population growth, respectively. In each case, two arbitrary, "high-case" and "low-case" assumptions are made, and their resulting impact on GDP growth is simulated using the framework presented in Section 3.1. ${ }^{39}$ Concretely, the "high" and "low" case assumptions considered are the following (see Table 4 for details):

- Annual TFP growth in countries close to the technological frontier: high and low case scenarios assume $2 \%$ and $1 \%$ average annual TFP growth over the projection period, respectively, versus $1.5 \%$ in the baseline scenario.

- Speed of convergence of TFP in lagging countries: assumed to converge gradually to $3 \%$ and $1 \%$ annual rates in the high and low case scenarios, respectively, versus $2 \%$ in the baseline scenario.

- Pace of human capital accumulation by new cohorts: assumed to tend towards average pace observed across the OECD over 1960-2000 - as opposed to the lower pace observed across the Averaging of Classical Estimates (BACE) approach, Sala-i-Martin et al. (2004) conclude to the existence of 18 significant growth determinants among a pool of 67 potential explanatory variables. 
world in the baseline scenario - in the high case scenario, and to zero - so that human capital increases through cohorts effects only from 2025 onwards - in low case scenario.

- Physical capital accumulation: capital/output ratios converge to one third above and below current US levels in the high and low case scenarios, respectively, versus the US level in the baseline scenario. Implicit to these alternative scenarios are alternative world saving rate assumptions. ${ }^{40}$

- Employment rates: the low-case scenario assumes no indexation of future effective retirement ages to life expectancy, as opposed to partial indexation in the baseline, while the high case scenario assumes full indexation and faster convergence - implicitly through labour market and pension reforms - of labour force participation rates in low-participation countries to the levels observed in those OECD countries where participation is highest.

- Population growth: The high, low and baseline scenarios are the high, low and baseline scenarios published by the United Nations.

\section{[Table 4. Sensitivity analysis: main features]}

23. Bearing in mind that these six different sensitivity exercises are not strictly comparable in the absence of any prior knowledge regarding the joint probability distribution of the six underlying parameters, the results confirm that any growth scenario is highly sensitive to assumptions regarding technological progress and population growth (Figure 1). Average annual world GDP growth up to 2050 could be about 1 percentage point higher (lower) than in the baseline under a combination of high case (low case) TFP and demographic scenarios, with significant variance across countries, however (Table 5). Assumptions regarding human capital and employment rates are comparatively less important over the projection horizon considered, in part because their growth effects ultimately fade out - at least in the framework adopted here, where human capital has no permanent effects on growth. Even under a combination of high case (low case) employment and human capital scenarios, average annual world GDP growth would be raised (lowered) by just $1 / 4$ percentage point. Capital intensity - and implicitly world saving - assumptions also affect only the level but not the growth of GDP. Nevertheless, the impact on annual GDP growth of the alternative scenarios considered here is still significant over the projection horizon, reaching almost 0.2 percentage points.

[Figure 1. Sensitivity analysis: World GDP growth under alternative scenarios]

\section{[Table 5. Sensitivity analysis: GDP growth in selected world regions under alternative scenarios]}

\section{Conclusion}

24. This paper has presented a simple, "conditional convergence" framework for projecting long-run GDP growth at the world level, taking stock of some of the current theoretical and empirical knowledge regarding long-run growth drivers, including the role of human capital accumulation. Special emphasis has also been put on the role of ageing populations and potential labour market and pension system reforms for future employment growth. This framework has been applied to project world GDP growth up to 2050, although extension to longer horizons is fairly straightforward. According to the baseline scenario

40 In the context of the production function framework adopted here, the low case scenario corresponds to steady-state world saving and investment rates being about 3.5 percentage points lower than in the baseline scenario. 
constructed here, world GDP would grow by about 4\% per year on average over the period 2006-2025 and by $3.5 \%$ over $2025-2050$. These projections were made in the course of 2008 and as such they do not factor in the sharp deterioration in world economic activity and forecasts of the second half of 2008. Incorporating the latter would imply a downward revision of world GDP growth over the next few years, but changes to projections up to 2050 would be fairly limited insofar as long-run potential growth remains little affected.

25. Long-run growth projections are inherently speculative due to model and parameter uncertainty, but also because the various determinants of growth would remain very hard to predict even in a hypothetical case where the "true" model were known. In this regard, simple sensitivity analysis confirms the major influence on future world GDP growth of productivity growth trends in countries close to the technological frontier and the speed of catch-up in countries lagging behind. A limitation of the simple long-term growth framework presented in this paper is that trade linkages across countries are ignored, and financial linkages are only roughly and indirectly incorporated. The single most important extension of this framework would be to model and project national saving rates - taking at least into account the influence of future demographic trends - and, via the world saving-investment equilibrium, world real interest rates and physical capital accumulation. A more comprehensive but costlier approach could be to plug the projections of growth drivers produced here - not least human capital and labour supply projections by cohorts - exogenously into a global macroeconomic model with overlapping generations, so as to project investment, saving and interest rates within a fully consistent framework. 


\section{BIBLIOGRAPHY}

Barro, R. and J-W. Lee (2001), "International Data on Educational Attainment: Updates and Implications", Oxford Economic Papers, Vol. 53, No. 3.

Barro, R. and J-W. Lee (1993), "International Comparisons of Educational Attainment", Journal of Monetary Economics, Vol. 32, No. 3.

Barro, R. and X. Sala-i-Martin (2004), Economic Growth, second edition, The MIT Press, Cambridge, Massachussets.

Bassanini, A. and S. Scarpetta (2001), "The Driving Forces of Economic Growth: Panel Data Evidence for the OECD Countries", OECD Economic Studies, No. 33.

Bassanini, A. and S. Scarpetta (2004), "Does Human Capital Matter for Growth in OECD Countries? A Pooled Mean Group Approach", Economics Letters, Vol. 74, No. 3.

Bils, M. and P. Klenow (2000), "Does Schooling Cause Growth?", American Economic Review, Vol. 90, No. 5.

Boarini, R. and H. Strauss (2007), "The Private Internal Rates of return to Tertiary Education: New Estimates for 21 OECD countries", OECD Economics Department Working Papers No. 591.

Bond, S., A. Leblebicioglu and F. Schiantarelli (2004), "Capital Accumulation and Growth: A New Look at the Empirical Evidence", Boston College Working Papers No. 591.

Burniaux, J-M., J. Chateau, R. Duval and S. Jamet (2008), "The Economics of Climate Change Mitigation: Policies and options for the Future", OECD Economics Department Working Papers No. 658.

Burniaux, J-M. and J. Chateau (2008), "An Overview of the OECD ENV-Linkages Model", OECD Economics Department Working Papers No. 653.

Burniaux, J-M., R. Duval and F. Jaumotte (2003), "Coping with Ageing: a Dynamic Approach to Quantify the Impact of Alternative Policy Options on Future Labour Supply", OECD Economics Department Working Papers No. 371.

Caselli, F. (2005), “Accounting for Cross-Country Income Differences", in P. Aghion and S. Durlauf (eds.), Handbook of Economic Growth, Elsevier, Amsterdam.

Caselli, F. and W. Coleman (2006), "The World Technology Frontier", American Economic Review, Vol. 96, No. 3.

Castles, I. and D. Henderson (2003a), "Economics, Emission Scenarios and the Work of the IPCC", Energy and Environment, Vol. 14, No. 4. 
Castles, I. and D. Henderson (2003b), "The IPCC Emission Scenarios: an Economic-Statistical Critique", Energy and Environment, Vol. 14, No. 2-3.

Cohen, D., and M. Soto (2007), "Growth and Human Capital: Good Data, Good Results", Journal of Economic Growth, Vol. 12, No. 1.

Easterly, W. and R. Levine (2001), "It's not Factor Accumulation: Stylized Facts and Growth Models", World Bank Economic Review, Vol. 15, No. 2.

Fisher, B., N. Nakicenovic, K. Alfsen, J. Corfee-Morlot, F. de la Chesnaye, J-C. Hourcade, K. Jiang, M. Kainuma, E. La Rovere, A. Matysek, A. Rana, K. Riahi, R. Richels, S. Rose, D. Van Vurren, and R. Warren (2007), "Issues Related to Mitigation in the Long-Term Context", in B. Metz, O. Davidson, P. Bosch, R. Dave and L. Meyer (eds.), Climate Change 2007: Mitigation. Contribution of Working Group III to the Fourth Assessment Report of the Inter-governemental Panel on Climate Change, Cambridge University Press, Cambridge.

Gemmel, R. (1996), "Evaluating the Impacts of Human Capital Stocks and Accumulation on Economic Growth: Some New Evidence", Oxford Bulletin of Economics and Statistics, Vol. 58, No. 1.

Groningen Growth and Development Centre (2006), "Data Sources and Methodology of the 60-Industry Database of the Groningen Growth and Development Centre", Groningen Growth and Development Centre, mimeo.

Hall, R. and C. Jones (1999), "Why Do Some Countries Produce So Much More Output than Others?", Quarterly Journal of Economics, Vol. 114, No. 1.

Harmon, C., H. Oosterbeek and I. Walker (2003), "The Returns to Education: Microeconomics", Journal of Economic Surveys, Vol. 17, No. 2.

Henderson, D. (2005), "The Treatment of Economic Issues by the Intergovernmental Panel on Climate Change", Energy and Environment, Vol. 16, No. 2.

Herve, K., I. Koske, N. Pain and F. Sedillot (2007), "Globalisation and the Macroeconomic Policy Environment", OECD Economics Department Working Papers No. 552.

Jones, C. (1997), “Convergence Revisited”, Journal of Economic Growth, Vol. 2, No. 2.

Klenow, P. and A. Rodriguez-Clare (1997), "The Neoclassical Revival in Growth Economics: Has it Gone Too Far?", in B. Bernanke and J. Rotemberg (eds.), NBER Macroeconomics Annual 1997, The MIT Press, Cambridge.

Mankiw, G., D. Romer and D. Weil (1992), "A Contribution to the Empirics of Economic Growth", Quarterly Journal of Economics, Vol. 107, No. 2.

McKibbin, W., D. Pearce and A. Stegman (2004), "Long-Run Projections for Climate Change Scenarios", Lowy Institute for International Policy, Working Papers in International Economics No. 1.04.

Nakicenovic, N., J. Alcamo, G. Davis, B. de Vries, J. Fenham, S. Gaffin, K. Gregory, A. Grübler, TY. Jung, T. Kram, E. La Rovere, L. Michaelis, S. Mori, T. Morita, W. Pepper, H. Pitcher, L. Price, K. Riahi， A. Reohrl, H. Rogner, A. Sankovski， M. Schlesinger，P. Shukla， S. Smith， R. Swart, S. Van Rooijen, N. Victor and Z. Dadi (2000), Special Report on Emission Scenarios. Working 
Group III, Inter-governemental Panel on Climate Change (IPCC), Cambridge University Press, Cambridge.

Neary, P. (2004), "Rationalizing the Penn World Table: True Multilateral Indices for International Comparisons of Real Income", American Economic review, Vol. 94, No. 5.

Nicoletti, G. and S. Scarpetta (2003), "Regulation, Productivity and Growth: OECD Evidence", OECD Economics Department Working Papers No. 347.

Nordhaus, W. (2007), "Alternative Measures of Output in Global Economic-Environmental Models: Purchasing Power Parity or Market Exchange Rates?", Energy Economics, Vol. 29, No. 3.

OECD (2004), Sources of Economic Growth, Paris.

Psacharopoulos, G. (1994), "Returns to Investment in Education: a Global Update", World Development, Vol. 22, No. 9.

Psacharopoulos, G., and H. Patrinos (2002), "Returns to Investment in Education: a Further Update", Education Economics, Vol. 12, No. 2.

Sala-i-Martin, X., G. Doppelhofer and R. Miller (2004), "Determinants of Long-Term Growth: A Bayesian Averaging of Classical Estimates (BACE) Approach”, American Economic Review, Vol. 94, No. 4.

Sianesi, B. and J. Van Reenen (2003), "The Returns to Education: Macroeconomics", Journal of Economic Surveys, Vol. 17, No. 2.

Timmer, M. and G. de Vries (2007), “A Cross-Country Database For Sectoral Employment And Productivity In Asia And Latin America, 1950-2005”, Groningen Growth and Development Centre, mimeo.

Van Ark, B. (1996), "Sectoral Growth Accounting and Structural Change in Post-War Europe", in B. Van Ark and N. Crafts (eds.), Quantitative Aspects of Post-War European Economic Growth, CEPR/Cambridge University Press, Cambridge.

Vanston, N. (2006), "Summary of a Workshop on Global Convergence Scenarios: Structural and Policy Issues", OECD Economics Department Working PapersNo. 483.

World Bank (2007), 2005 International Comparison Program: Preliminary results, 17 December 2007, The World Bank, Washington D.C. 


\section{ANNEX: DATA SOURCES AND METHODOLOGY}

This Annex presents further details on the sources and methodology used to construct the data used in the long-term growth framework.

\section{1. $\quad G D P$}

\section{Definition: Real GDP in 2005 constant PPP US\$}

Source: OECD Economic Outlook (hereafter, EO); World Bank, Word Development Indicators database (hereafter, WDI) for GDP and World Bank (2007) for 2005 PPP exchange rates; ${ }^{41}$ IMF, World Economic Outlook (hereafter, WEO);

Data adjustments: GDPs in local currency are converted in PPP US\$ for the year 2005, using World Bank PPP estimates. GDPs are then extrapolated backwards to 1995 and forward to 2006 using real GDP growth rates in national currency. Finally, GDPs in constant 2005 PPP US\$ for the years 2007 and 2008 are obtained by extrapolating 2006 GDP data using projected GDP growth rates as published in EO82 (for OECD countries and Brazil, Russia, India and china) and the October 2007 issue of the WEO (for other countries).

For countries where fossil fuels extraction makes a sizeable share of output, convergence scenarios are applied to GDP excluding the mining and quarrying sector (OPEC countries, Azerbaidjan, Kazakhstan, Bahrein, Israel, Jordan, Oman, Syrian Arab Republic, Yemen, Brunei Darussalam, Norway and Russia). The share of this sector in total value added is calculated from the United Nations National Accounts. For most countries, the latest year available was 2005 .

\section{Employment}

Labour Force

Definition: Labour force aged 15 and over.

Source: OECD, Labour Force Statistics (hereafter, LFS); OECD Employment Outlook; International Labour Organisation, Labour Force Survey (hereafter ILO); WDI; WEO; EO; for China, Statistical Yearbook 2007; for India, Report no 522, National Sample Survey, National Sample Survey Organisation, Ministry of Statistics and Programme Implementation. Primary sources are LFS for OECD countries, The OECD Employment Outlook for Brazil and the Russian Federation, national sources for China and India, and ILO or WDI for other countries up to 2006 (or the latest available year).

Data adjustments: Over the period 2007-2008, EO and WEO projections are used to extrapolate labour force data for OECD and other countries, respectively. Any missing values over the period 19952006 are filled in using alternative data sources available and/or linear interpolation.

\footnotetext{
${ }^{41}$ For those few countries where no 2005 PPP exchange rates are published in World Bank (2007), PPP estimates for the year 2000 are used, as published in WDI. The countries concerned are Algeria, the United Arab Emirates and some Central American countries.
} 
ECO/WKP(2009)4

\section{Unemployment}

Unemployment of individuals aged 15 and over is taken from similar sources as labour force data, and is subject to the same data adjustments.

\section{Employment}

Employment is calculated as labour force minus unemployment.

Employment rates are calculated as the ratio of employment to population aged 15 and over.

\section{Population}

Population data are available by cohorts (5-year age groups) and are taken from United Nations population projections.

\section{Human capital stock}

Definition: Average number of years of schooling of population aged 25-64 (then converted into a human capital stock measure, based on explicit assumptions about social returns from education)

Source: Cohen-Soto database; Barro-Lee dataset. The primary source is the Cohen-Soto database, which provides average years of education by 5 -years age groups. The average number of years of education across the population aged 25-64 can then be projected by cohorts, based on a single educational attainment scenario for the 25-29 age group.

For some countries, data by cohorts are unavailable (Croatia, Czech Republic, Hong-Kong, Iceland, Pakistan, Poland, Russia, Slovakia, Slovenia and South Africa), The Barro-Lee dataset is then used in those cases, and the average number of years of education across the population aged 25-64 is projected directly.

\section{Physical capital stock}

Definition: Real aggregate capital stock in constant 2005 national currency prices.

Source: WDI, WEO and Statistical Yearbook for Russia.

Data adjustments: Historical real investment and GDP series are taken from WDI and extrapolated up to 2008 using EO82 and October 2007 WEO projections. A capital stock to GDP ratio is then derived using the so-called perpetual inventory method . For a few Eastern European countries where investment series are too short to derive reliable capital stock estimates from the perpetual inventory method, strong assumptions are made regarding the initial value of the capital stock. For Croatia, Czech Republic, Poland, Slovakia and Slovenia, the capital/output ratio is assumed to be similar to that of Hungary (which is available) in 1990, and the perpetual inventory method is applied starting only from 1991 to extrapolate the capital stock up to 2008. For Estonia, Latvia and Lithuania, the capital/output ratio is assumed to be similar to that of Russia in 1995. For Romania, the capital/output ratio is assumed to be similar to that of Bulgaria in 1990 . 
ECO/WKP(2009)4

Table 1. Decomposition of cross-country differences in GDP per capita into their broad determinants, $2005^{1,2}$

\begin{tabular}{|c|c|c|c|c|c|}
\hline \multicolumn{6}{|c|}{$($ United States $=100)$} \\
\hline & GDP PPP per capita & TFP & Human capital & Physical capital & Employment \\
\hline & Y/Pop & A & $\mathrm{h}$ & $(K / Y)^{\alpha /(1-\alpha)}$ & L/Pop \\
\hline United States & 100.0 & 100.0 & 100.0 & 100.0 & 100.0 \\
\hline Canada & 83.5 & 72.0 & 103.3 & 105.8 & 106.0 \\
\hline Japan & 72.6 & 52.6 & 100.4 & 130.7 & 105.1 \\
\hline China & 9.8 & 13.6 & 57.3 & 105.2 & 119.5 \\
\hline India & 5.2 & 12.7 & 47.7 & 98.3 & 87.1 \\
\hline Brazil & 20.5 & 29.3 & 70.1 & 103.1 & 96.8 \\
\hline Russian Federation & 28.6 & 31.5 & 84.9 & 97.4 & 99.3 \\
\hline Australia-New Zealand $^{3}$ & 78.3 & 64.1 & 101.5 & 114.8 & 104.5 \\
\hline $\mathrm{EU} 27+\mathrm{EFTA}^{3}$ & 64.7 & 67.8 & 91.2 & 114.1 & 91.3 \\
\hline Rest of the World ${ }^{3}$ & 12.3 & 20.9 & 59.7 & 103.6 & 81.7 \\
\hline Total World $^{3}$ & 22.8 & 27.9 & 64.2 & 104.2 & 95.8 \\
\hline
\end{tabular}

1. While equal in principle, $Y / P o p$ and the product of $A, h,(K / Y)^{\text {artrat }}$ and $L / P o p$ can differ in practice for two reasons: First, for countries where fossil fuels extraction makes a sizeable share of overall output (Russian Federation and a number of countries in the Rest of the World aggregate), TFP levels were estimated for total output excluding the mining and quarrying sector, for reasons explained in the text. Second, geographical area aggregates are computed as arithmetic averages, while geometric means would have to be used for the equality $\mathrm{Y} / \mathrm{Pop}=\mathrm{A} h(\mathrm{~K} / \mathrm{Y}){ }^{\alpha /(1-\alpha)} \mathrm{L} / \mathrm{Pop}$ to hold.

2. The long-term growth framework is applied at the individual country level. The geographical disaggregation of the world economy presented here matches that of the OECD ENV-Linkages model, as used in Burniaux et al. (2008).

3. Population-weighted arithmetic averages.

Source: Authors' calculations. 
Table 2. Baseline economic scenario: main features ${ }^{1}$

(Average annual growth rates, PPPs US\$)

\begin{tabular}{|c|c|c|c|c|c|c|c|c|c|}
\hline & \multicolumn{3}{|c|}{ GDP per worker } & \multicolumn{3}{|c|}{ GDP per capita } & \multicolumn{3}{|c|}{ GDP } \\
\hline & $2000-2006$ & 2006-2025 & $2025-2050$ & $2000-2006$ & $2006-2025$ & $2025-2050$ & $2000-2006$ & $2006-2025$ & $2025-2050$ \\
\hline United States & 1.7 & 1.7 & 1.6 & 1.6 & 1.6 & 1.6 & 2.6 & 2.4 & 2.2 \\
\hline Canada & 0.7 & 2.0 & 1.7 & 1.6 & 1.9 & 1.6 & 2.6 & 2.7 & 2.1 \\
\hline Japan & 1.7 & 1.9 & 1.9 & 1.5 & 1.7 & 1.5 & 1.6 & 1.5 & 0.8 \\
\hline China & 8.6 & 6.4 & 3.7 & 9.0 & 6.1 & 3.3 & 9.7 & 6.6 & 3.2 \\
\hline India & 5.0 & 5.2 & 4.6 & 5.6 & 6.3 & 5.1 & 7.3 & 7.6 & 5.6 \\
\hline Brazil & 0.0 & 2.5 & 3.3 & 1.5 & 3.0 & 3.5 & 2.9 & 4.0 & 3.9 \\
\hline Russian Federation & 5.4 & 3.8 & 2.5 & 6.7 & 4.0 & 2.5 & 6.2 & 3.4 & 1.8 \\
\hline Australia-New Zealand & 0.9 & 2.0 & 1.7 & 1.9 & 2.0 & 1.6 & 3.1 & 2.9 & 2.1 \\
\hline EU27 + EFTA & 1.1 & 2.1 & 1.8 & 1.7 & 2.3 & 1.8 & 2.1 & 2.4 & 1.7 \\
\hline OPEC + Other oil producers & 1.9 & 2.3 & 3.7 & 2.9 & 3.0 & 4.2 & 4.8 & 4.4 & 5.0 \\
\hline Rest of the World & 2.1 & 3.1 & 3.5 & 2.8 & 3.3 & 3.7 & 4.5 & 4.9 & 4.7 \\
\hline Total World & 2.0 & 2.5 & 2.8 & 2.5 & 2.8 & 2.9 & 3.7 & 3.8 & 3.4 \\
\hline \multicolumn{10}{|l|}{ Total World in constant 2005} \\
\hline MERs US\$ & & 1.9 & 2.3 & & 2.2 & 2.4 & & 3.2 & 3.0 \\
\hline
\end{tabular}

1. The long-term growth framework is applied at the individual country level. The geographical disaggregation of the world economy presented here matches that of the OECD ENV-Linkages model, as used in Burniaux et al. (2008).

Source: Authors' calculations. 
ECO/WKP(2009)4

Table 3. Baseline economic scenario: population and employment projections ${ }^{1}$

\begin{tabular}{|c|c|c|c|c|c|c|}
\hline & \multicolumn{3}{|c|}{ Population growth, average annual } & \multicolumn{3}{|c|}{ Employment rates ${ }^{2}$, average } \\
\hline & $2000-2006$ & $2006-2025$ & $2025-2050$ & $2000-2006$ & $2007-2025$ & $2026-2050$ \\
\hline United States & 1.0 & 0.8 & 0.5 & 60.0 & 58.5 & 56.6 \\
\hline Canada & 1.0 & 0.8 & 0.5 & 60.3 & 60.8 & 57.9 \\
\hline Japan & 0.1 & -0.3 & -0.7 & 58.2 & 55.8 & 51.8 \\
\hline China & 0.7 & 0.5 & -0.1 & 72.6 & 68.9 & 60.5 \\
\hline India & 1.6 & 1.2 & 0.5 & 61.8 & 64.3 & 68.8 \\
\hline Brazil & 1.4 & 1.0 & 0.4 & 61.7 & 64.0 & 63.6 \\
\hline Russian Federation & -0.5 & -0.6 & -0.7 & 54.7 & 58.0 & 58.8 \\
\hline Australia-New Zealand & 1.2 & 0.9 & 0.5 & 60.5 & 61.6 & 58.4 \\
\hline EU27 + EFTA & 0.3 & 0.1 & -0.1 & 51.2 & 53.5 & 53.4 \\
\hline OPEC + Other oil producers & 1.8 & 1.5 & 0.8 & 52.6 & 54.8 & 55.2 \\
\hline Rest of the World & 1.7 & 1.5 & 1.0 & 60.2 & 60.1 & 57.8 \\
\hline Total World & 1.2 & 1.0 & 0.5 & 61.6 & 61.6 & 59.9 \\
\hline
\end{tabular}

1. The long-term growth framework is applied at the individual country level. The geographical disaggregation of the world economy presented here matches that of the OECD ENV-Linkages model, as used in Burniaux et al. (2008).

2. Defined as employment as a percentage of population aged 15 and over.

Source: Authors' calculations. 
Table 4, Sensitivity analysis: World GDP growth under alternative scenarios

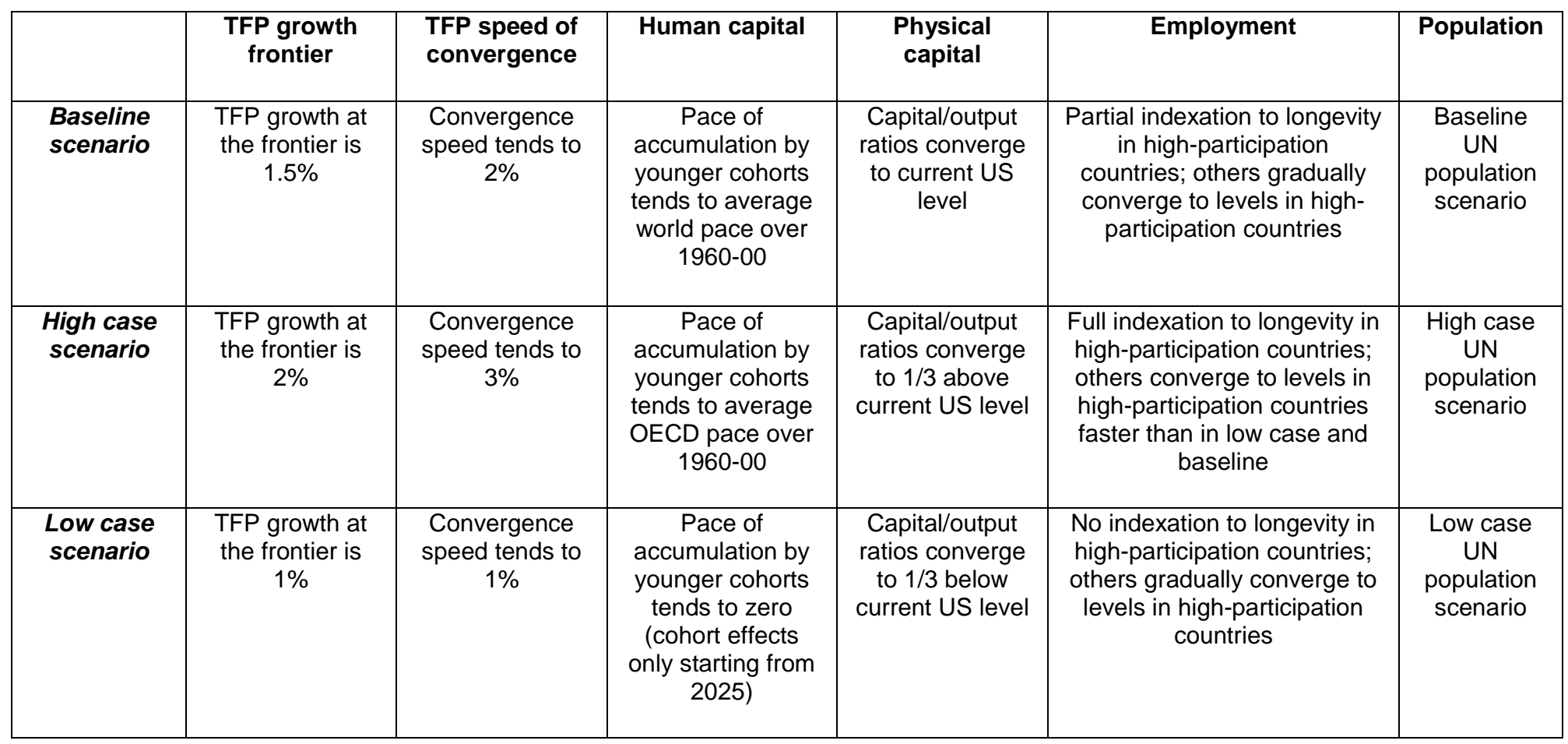


ECO/WKP(2009)4

Table 5. Sensitivity analysis: GDP growth in selected world regions under alternative scenarios, average 2006-2050

(Gap with respect to baseline in percentage points)

\begin{tabular}{|c|c|c|c|c|c|c|}
\hline \multicolumn{7}{|c|}{ Panel A. High case scenario } \\
\hline & TFP growth & TFP catch-up & Population & $\begin{array}{c}\text { Physical } \\
\text { capital }\end{array}$ & Employment & Human capital \\
\hline United States & 0.4 & 0.0 & 0.2 & 0.3 & 0.1 & 0.0 \\
\hline Canada & 0.4 & 0.0 & 0.2 & 0.2 & 0.1 & 0.0 \\
\hline Japan & 0.4 & 0.1 & 0.2 & 0.1 & 0.2 & 0.0 \\
\hline China & 0.5 & 0.4 & 0.2 & 0.2 & 0.1 & 0.1 \\
\hline India & 0.5 & 0.5 & 0.3 & 0.2 & 0.2 & 0.2 \\
\hline Brazil & 0.5 & 0.3 & 0.2 & 0.3 & 0.1 & 0.1 \\
\hline Russian Federation & 0.5 & 0.2 & 0.3 & 0.2 & 0.2 & 0.1 \\
\hline Australia-New Zealand & 0.5 & 0.1 & 0.2 & 0.2 & 0.1 & 0.0 \\
\hline EU27 + EFTA & 0.4 & 0.0 & 0.2 & 0.1 & 0.2 & 0.0 \\
\hline OPEC + Other oil producers & 0.5 & 0.2 & 0.2 & 0.2 & 0.2 & 0.0 \\
\hline Rest of the World & 0.5 & 0.3 & 0.2 & 0.2 & 0.2 & 0.1 \\
\hline Total World & 0.5 & 0.2 & 0.2 & 0.2 & 0.2 & 0.1 \\
\hline \multicolumn{7}{|c|}{ Panel B. Low case scenario } \\
\hline & TFP growth & TFP catch-up & Population & $\begin{array}{c}\text { Physical } \\
\text { capital }\end{array}$ & Employment & Human capital \\
\hline United States & -0.4 & 0.0 & -0.2 & -0.2 & -0.1 & -0.1 \\
\hline Canada & -0.4 & -0.1 & -0.2 & -0.2 & -0.1 & 0.0 \\
\hline Japan & -0.4 & -0.2 & -0.2 & -0.2 & -0.1 & 0.0 \\
\hline China & -0.5 & -0.5 & -0.3 & -0.3 & -0.1 & -0.2 \\
\hline India & -0.5 & -0.6 & -0.3 & -0.2 & -0.1 & -0.3 \\
\hline Brazil & -0.5 & -0.4 & -0.3 & -0.2 & -0.1 & -0.1 \\
\hline Russian Federation & -0.5 & -0.2 & -0.3 & -0.2 & -0.1 & -0.2 \\
\hline Australia-New Zealand & -0.5 & -0.1 & -0.2 & -0.2 & -0.1 & 0.0 \\
\hline EU27 + EFTA & -0.4 & 0.0 & -0.2 & -0.2 & -0.1 & 0.0 \\
\hline OPEC + Other oil producers & -0.5 & -0.3 & -0.3 & -0.2 & -0.1 & -0.1 \\
\hline Rest of the World & -0.5 & -0.3 & -0.3 & -0.3 & -0.1 & -0.2 \\
\hline Total World & -0.5 & -0.3 & -0.3 & -0.2 & -0.1 & -0.1 \\
\hline
\end{tabular}

1. The long-term growth framework is applied at the individual country level. The geographical disaggregation of the world economy presented here matches that of the OECD ENV-Linkages model, as used in Burniaux et al. (2008).

Source: Authors' calculations. 
Figure 1. Sensitivity analysis: World GDP growth under alternative scenarios, average 2006-2050

(Gap with respect to baseline in percentage points)

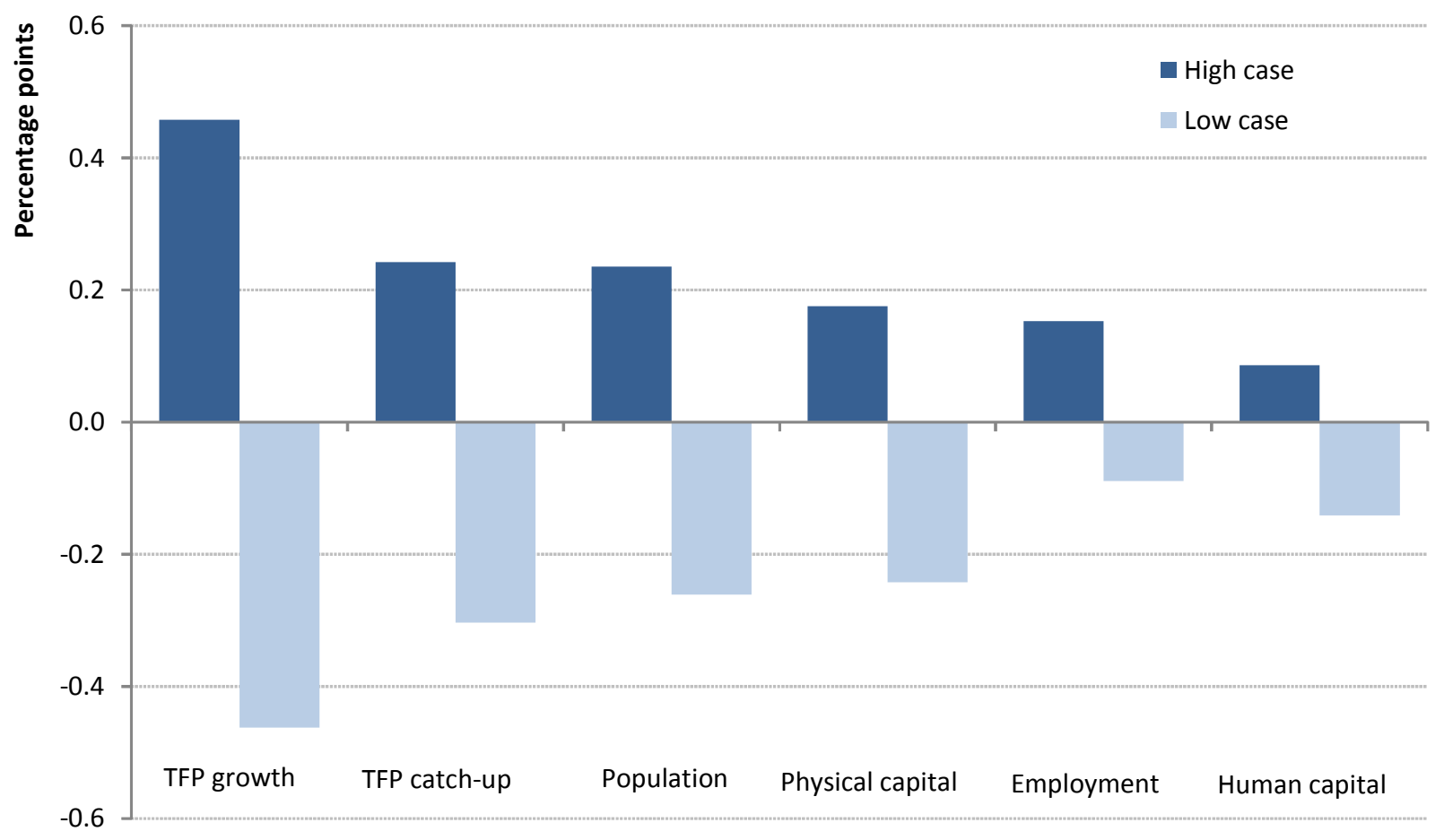

Source: Authors' calculations. 


\section{WORKING PAPERS}

The full series of Economics Department Working Papers can be consulted at www.oecd.org/eco/Working_Papers/

662. Realising South Africa's employment potential (January 2009) Geoff Barnard

661. Making the most of Norwegian schools (January 2009) Romina Boarini

660 Can the financial sector continue to be the main growth engine in Luxembourg? (January 2009) Arnaud Bourgain, Patrice Pieretti and Jens Høj

659. Fiscal policy responsiveness, persistence, and discretion (December 2008) António Afonso, Luca Agnello, Davide Furceri

658. The economics of climate change mitigation: policies and options for the future (December 2008) Jean-Marc Burniaux, Jean Chateau, Romain Duval and Stéphanie Jamet

657. Maximising Mexico's gains from integration in the world economy (December 2008) David Haugh, Roselyne Jamin and Bruno Rocha

656. How do taxes affect investment and productivity? An industry-level analysis of OECD countries (December 2008) Laura Vartia

655. Strategies for countries with favourable fiscal positions (November 2008) Robert Price, Isabelle Joumard, Christophe André and Makoto Minegishi

654. Monetary transmission mechanism in Central and Eastern Europe: Surveying the Surveable (November 2008) Balázs Égert and Ronald MacDonald

653. An Overview of the OECD ENV-Linkages Model Jean-Marc Burniaux and Jean Château

652. Reforming the labour market in Japan to cope with increasing dualism and population ageing (November 2008) Randall S. Jones

651. Enhancing the productivity of the service sector in Japan (November 2008) Randall S. Jones and Taesik Yoon

650. Reforming the tax system in Japan to promote fiscal sustainability and economic growth (November 2008) Randall S. Jones and Masahiko Tsutsumi

649. What Drives the NAIRU? Evidence from a Panel of OECD Countries (November 2008) Christian Gianella, Isabell Koske, Elena Rusticelli and Olivier Chatal

648. Short-term distributional effects of structural reforms: selected simulations in a DGSE framework (October 2008) Annabelle Mourougane and Lukas Vogel 


\section{ECO/WKP(2009)4}

647. Speed of adjustment to selected labour market and tax reforms

(October 2008) Annabelle Mourougane, Lukas Vogel

646. The challenge of monetary policy in Turkey

(October 2008) Olcay Çulha, Ali Çulha and Rauf Gönenç

645. Improving cost-effectiveness in the health-care sector in Iceland

(October 2008) Hannes Suppanz

644. Understanding Russian regions' economic performance during periods of decline and growth - an Extreme Bound Analysis approach

(October 2008) Rüdiger Ahrend

643. Do tax structures affect aggregate economic growth? Empirical evidence from a panel of OECD countries

(October 2008) Jens Arnold

642. Accounting for one-off operations when assessing underlying fiscal positions

(October 2008) Isabelle Joumard, Makoto Minegishi, Christophe André, Chantal Nicq and Robert Price

641. Do corporate taxes reduce productivity and investment at the firm level? Cross-country evidence from the Amadeus dataset

(October 2008) Cyrille Schwellnus and Jens Arnold

640. The challenge of rapidly improving transport infrastructure in Poland

(September 2008) Rafal Kierzenkowski

639. Bridging the housing gap in Poland

(September 2008), Rafal Kierzenkowski

638. Improving the business and investment climate in Indonesia

(September 2008), Diego Moccero

637. Growth performance and policy challenges

(September 2008), Luiz de Mello

636. A taxonomy of instruments to reduce greenhouse gas emissions and their interactions

(September 2008), Romain Duval

635. Quantifying the effect of financial conditions on US activity

(September 2008) Stéphanie Guichard and David Turner

634. Have long-term financial trends changed the transmission of monetary policy

(September 2008), Stéphanie Guichard and David Turner

633. Raising education achievement and breaking the cycle of inequality in the United Kingdom (August 2008) Anne-Marie Brook

632. The euro changeover in the Slovak Republic: implications for inflation and interest rates (August 2008) Felix Hüfner and Isabell Koske 